\title{
Belphégor
}

\section{Distinctions that Matter : Popular Literature and Material Culture}

\section{Anthony Enns and Bernhard Metz}

\section{(2) OpenEdition}

1 Journals

\section{Electronic version}

URL: http://journals.openedition.org/belphegor/606

DOI: 10.4000/belphegor.606

ISSN: 1499-7185

Publisher

LPCM

\section{Electronic reference}

Anthony Enns and Bernhard Metz, « Distinctions that Matter : Popular Literature and Material Culture », Belphégor [Online], 13-1 | 2015, Online since 11 July 2015, connection on 10 December 2020. URL : http://journals.openedition.org/belphegor/606 ; DOI : https://doi.org/10.4000/belphegor.606

This text was automatically generated on 10 December 2020.

\section{(c) (i) (9)}

Belphégor est mis à disposition selon les termes de la Licence Creative Commons Attribution - Pas d'Utilisation Commerciale - Pas de Modification 4.0 International. 


\title{
Distinctions that Matter : Popular Literature and Material Culture
}

\author{
Anthony Enns and Bernhard Metz
}

1 This issue of Belphégor explores the various relationships and interdependencies between book production and distinctions of taste by examining how the material aspects of literary texts, such as the cover, binding, typography, and paper stock, reflect or even determine their cultural status. For example, a reduction in size or the use of cheaper materials and technologies could decrease costs and increase profits, as the text could be produced in larger quantities and marketed to a broader readership, yet such a marketing strategy (including different forms of distribution) could also involve the loss of at least a certain degree of cultural prestige. The use of more expensive materials and production technologies could elevate a text's cultural prestige, yet prestige is directly proportional to rarity, which limits the circulation of a text and thus its profitability. In many cases, the distinctions between "highbrow" and "lowbrow" texts had little to do with the contents of the texts themselves. In fact, it was largely unimportant whether the people purchasing these books actually read them, as books more often functioned as markers of socioeconomic status, like clothing or home décor.

2 At the risk of being provocative, one might even go so far as to say that the concept of literary taste, at least since the eighteenth century, has historically been more closely related to fashion sense than critical judgment, although such a claim clearly challenges the hermeneutic and philosophical tradition upon which these distinctions rely for their continued relevance. ${ }^{1}$ It is precisely this provocative claim that the contributions in this issue attempt to address by examining the tensions between commerce and prestige in the history of book production over the last three centuries. They explore the degree to which the low cultural status of popular literature can be understood as an inherent consequence of the industrialization of print in the nineteenth century and how the material form of a book often changes the value of texts otherwise experienced as less prestigious.

3 From this perspective, one of the most significant consequences of the Industrial Revolution was that printing became cheaper, faster, and more easily accessible than ever 
before. $^{2}$ This process began with the development of automatic paper-making machines, which were first invented by the Foudrinier brothers in England in 1803. Their belt-based machine was capable of producing more paper in a single day than workers could produce by hand in a week. In 1816 Thomas Gilpin also developed a cylindrical machine that allowed paper to be produced in large widths on a continuous roll. Up to that date, the size of the wire mould restricted the maximum size of the full sheet and the format of paper books. By 1830 machine-made paper was being used for the majority of all print material, including books. ${ }^{3}$ The invention of non rag-based paper and the introduction of "Esparto" grass and later wood pulp further reduced printing costs. In the U.S., for example, the price of paper fell dramatically from roughly seventeen cents per pound in 1870 to seven cents per pound in $1889,{ }^{4}$ while in the U.K. the price fell from ten pence per pound in 1836 to two pence per pound in $1902 .^{5}$

In 1800 the British scientist Charles Mahon, Third Earl of Stanhope, introduced a leverpowered iron printing press that had several advantages over the wooden press, as the lever mechanism required less effort and delivered greater pressure, more evenly, with a larger platen. ${ }^{6}$ It was also possible to operate it with a single printer, thus reducing labor costs. Soon after the Stanhope press was introduced, Friedrich Koenig, a German engineer living in the U.K., invented a steam-driven press that printed roughly 1,000 pages per hour, which was considerably faster than the 300 pages per hour produced by the leverpowered press. In 1848 the English inventor Augustus Applegarth also developed a vertical rotary press, in which the printing surface was attached to the cylindrical surface and rotated against the platen. Paper could be fed into the Applegarth press from four different angles to produce 4,000 pages per hour. By 1850 paper could be fed into this press from eight different angles to produce 10,000 pages per hour. In 1858 the American inventor Richard M. Hoe also introduced a horizontal rotary press, which had up to ten feeding stations and was capable of producing up to 20,000 pages per hour. Hoe's press soon became the standard technology for printing newspapers.

5 The nineteenth century saw also several innovations in bookbinding, such as the development of a stabbing machine in 1820, a rolling press in 1840, a folding machine in 1843, a rounder and backer in 1854, and various "gilding, marbling, cutting, and trimming machines." By the end of the century, machines to fold sheets for binding into books were also in use, and the process of cutting, gathering, stritching, stapling, and gluing pages was entirely mechanized. The industrialization of printing changed not only the printing profession, but also the look of books. ${ }^{8}$ It also led to important changes in the social structure of printing shops, as more and more unlearned workers, including women and children, entered a status-conscious profession that was traditionally wellpaid and organized in guilds.

6 The techniques of illustration and pictorial reproduction also went through enormous changes during the nineteenth century. While older technologies like wood and steel engraving were perfected and economized during this period, the invention of lithography by Alois Senefelder particularly revolutionized the printing business. Lithography also gave way to color printing, which was first introduced by Senefelder as color lithography in 1818 and practically applied in $1826.9^{9}$ The patent for "chromolithography" was given to Godefroy Engelmann in 1837, and this technique remained in use until late in the twentieth century. The emergence and widespread availability of popular literature was also connected to these new technologies, as many illustrated journals had high print runs and combined popular content with pictures for a 
mass public. Even though most of the books printed between 1830 and 1914 were not illustrated, Michael Twyman argues that "the illustrated book was a major factor in defining publishing in the period, and that it changed the concept of the book for good."10

7 The expansion of stereotyping in the 1830s and 1840s also allowed printers to reprint a text at a later date without having to pay the composition costs a second time or the storage costs for unused standing type. The development of mechanical typesetting machines like the Pianotype or the Kastenbein reduced printing costs even further by automating the process of composition, which once again led to innovations in the social structure of typesetters since less-paid women entered the realm of machine typesetting. ${ }^{11}$ The first successful mechanical hot lead typesetting machine was the Linotype, which was invented by a German watchmaker named Ottmar Mergenthaler in the 1880s. At roughly the same time American inventor Tolbert Lanston developed the Monotype system, which consisted of a separate keyboard and a caster..$^{12}$ These machines were able to compose texts much faster than by hand and solved the problem of redistributing type after usage by melting it. They remained the standard method of composition until the development of phototypesetting devices and computerized prepress systems in the twentieth century. The Linotype and Monotype systems also introduced their own typefaces according to technical restrictions and specifications, which were later adapted for other typesetting devices and word processing software. Some of them are still commonly used to this day, such as Times New Roman, the most widely used typeface of the twentieth century, which was developed by Stanley Morison for The Times of London in $1931 .{ }^{13}$

8 As a result of this combination of high-speed presses, machine-made paper, publisher's bindings, and composing machines, all of the basic elements of the printing process could be mechanized and eventually automated. As these machines required less human labor (and also less well-paid and specialized labor), there was a rapid decrease in printing costs and a tremendous increase in the quantity of print runs, which resulted in a sudden explosion of print material in the late nineteenth and early twentieth century. In the U.K., for example, book production rose to over 5,000 titles per year in the 1850 s, and by 1910 book production was up to 10,000 titles per year. ${ }^{14}$ In the U.S., book production was at 4,500 titles per year in 1890, and by 1914 it was up to 12,000 titles per year. ${ }^{15}$ The increase in book production was even more dramatic in Germany, where it rose steadily from 10,000 titles per year in 1850 to 35,000 titles per year in 1913, making this nation the leading book producer in the world. ${ }^{16}$ Between 1900 and 1913, the publishing industry also became the third-largest business in the world. ${ }^{17}$ As Steven Roger Fischer points out, this increase in book production was due to a wide range of social changes, including "accelerated urbanization, a higher standard of living, a more sophisticated educational system and higher technical training." ${ }^{18}$ These changes led to a greater demand for print material across Europe and North America, as a decrease in the working day and improved education resulted in a sudden increase in literacy rates, particularly among women and the working class. By the 1890s more than 95 percent of the population in advanced countries could read and write, which resulted in the emergence of a mass reading public.

9 The question as to whether technological innovations caused the rise of mass literacy or whether mass literacy was the driving force behind these technological innovations has become a major source of debate among historians of the book. While most historians argue that mass literacy was a direct result of the Industrial Revolution, historians like 
John Feather argue that technological innovations were designed to meet pressing social needs. ${ }^{19}$ Martyn Lyons similarly claims that "the industrialization of the book [...] was a response to the expanding possibilities of the market." ${ }^{20}$ Other critics, like Cathy $\mathrm{N}$. Davidson, dismiss this unanswerable question by describing it as an irrelevant "chickenor-egg style ontogenetic debate." ${ }^{21}$ Nevertheless, it is clear that the increase in both the supply and demand for books led to what is known as a "reading revolution" in the nineteenth century. As Rolf Engelsing famously argued (although criticized in many details), in the case of Germany, people went from reading a few books intensively to reading a wide range of books only once, and reading went from being an oral practice performed in groups to a solitary practice conducted in silence. Books thus lost much of their ritual and religious function and became in some cases nothing more than disposable commodities, while readers went from being engaged participants to passive consumers. The development of subjectivity and book-based individuality is likewise discussed as being a result of the increase of silent reading. ${ }^{22}$ This theory obviously does not encompass all readers and reading practices, and certain books continue to be read intensively or aloud today, as is evident by the continued popularity of bible study groups and book clubs, yet it is undoubtedly true that there was a far greater demand for print material in the late nineteenth century, as more people were reading than ever before.

Since costs decreased and demand increased, books gradually became cheaper than ever before. In the 1820s, for example, the first edition of a novel in the U.K. would consist of three volumes, which were priced at 31s $6 \mathrm{~d}$ (these books were known as "three-deckers"). By the 1830s single-volume reprint editions were priced at five or six shillings. In 1849 George Routledge began selling smaller reprint editions for one or two shillings (these books were known as "yellowbacks" because they were commonly bound in glazed yellow boards). In 1883 Routledge also started a "Universal Library" at the price of one shilling a volume. In 1885 Cassell answered with their "National Library" at a price of three pence in paper and six pence in cloth. Routledge's reaction was a "World Library" at the same price. Both publishers thus "entered into an all-out price war." ${ }^{23}$ The "underselling" of books (selling books below their advertised price) was also a common practice at this time. ${ }^{24}$ Simon Eliot and Andrew Nash emphasize the tremendous flexibility in this pricing system: "[W]ithin a matter of a few years a reader could buy a novel, which had originally appeared at $31 \mathrm{~s} 6 \mathrm{~d}$, at $1 / 63 \mathrm{rd}$ or less of its original price-a price flexibility that even computer manufacturers today would find hard to match." ${ }^{25}$ While each of these editions was designed to target a different sector of the market, competition between publishers made this pricing system unsustainable over the long term, and by 1900 the three-decker had entirely disappeared. After this time, most new novels were published in one volume and priced at six shillings.

11 In Germany, cheap paperback editions appeared as early as 1841, when Leipzig publisher Christian Bernhard Tauchnitz began printing one title a week. In 1867 Reclam's "Universal Bibliothek" started as a series of paperback editions that sold for one groschen each.$^{26}$ As a result, cheap paperback editions flooded the market. ${ }^{27}$ In France, Charpentier began producing small, single-volume editions at a reduced price in the 1830s. In 1848 Gustave Havard published a paperback edition of Prevost's Manon Lescaut, which was priced at only 20 centimes. It was a tremendous success, and by 1856 Havard had reportedly published sixty million books. ${ }^{28}$ In 1855 Michel Lévy also began publishing contemporary novels that were priced at one franc. In the 1890s "Flammarion and Fayard priced their new series of fiction even lower," and by 1913 French readers could buy 
novels for only 10 centimes. ${ }^{29}$ Similar price reductions also appeared in North America with the rise of dime novels, in Italy with the rise of one-lira novels, and in Spain with the rise of one-peseta novels. As books became smaller and cheaper they were also sold in venues outside the traditional bookstore, such as railway stations-a practice that began as early as 1848 in London and 1853 in Paris. ${ }^{30}$ In 1912 German publisher Reclam also began installing book vending machines in bookstores, railway stations, and hospitals. The tremendous expansion of the book market through cheap paperbacks was thus an international phenomenon.

The introduction of new publishing formats was also accompanied by the introduction of new content, as Simon Eliot and Andrew Nash point out : "[W]ith the decline of the threevolume form came the rise of identifiable branches of genre fiction, such as romance, spy fiction, detective fiction and science fiction [...]. At the bottom end of the price scale was the shilling shocker [...] which became especially successful in the late Victorian period." ${ }^{31}$ In other words, there was a direct connection between the expansion of the book market and the rise of popular genre fiction. The serial (or serialized) novel was also introduced with remarkable success, as novels by such renowned authors as Balzac or Dickens were first published in newspapers and journals and were later republished as book editions or parts of books. ${ }^{32}$ Publishers also began employing new marketing strategies to announce and promote their books, including posters, press advertisements, and book reviews, which led to the birth of the "best-seller."

As Joseph McAleer points out, popular reading and publishing expanded even further in the early twentieth century, as higher production costs and lower profit margins forced publishers to "accelerate the movement towards cheap-priced books, and to accommodate more closely the tastes of the lower-middle and working class." ${ }_{33}$ This increase was largely due to a wave of paperback editions, which was initiated by Penguin in 1935. Penguin was founded with the explicit aim of making books available for a low price, and the first Penguin paperback cost only $6 \mathrm{~d}-$ the price of a pack of cigarettes. This strategy proved to be a great success, as Penguin sold over 3 million paperbacks by the end of 1936. In 1937 Penguin also introduced the "Penguincubator"-a vending machine for paperbacks that was placed in Woolworth department stores and railway stations. In Germany, Ullstein also introduced their yellow series ("Gelbe Reihe"), which sold remarkably well, especially during the holidays. ${ }^{34}$ While most paperbacks featured genre fiction, such as westerns, whodunits, and romances, some publishers also reprinted classic works of literature, yet these books "suffered initially from a taint of commercialism caused partly by its humble sales outlets and partly by the lurid covers produced for many of its early titles." 35

14 Michael Winship explains how these changes altered the role of the publisher:

For the first time, the publisher was responsible not only for the typography and appearance of the printed sheets but also for the design and production of the binding in which they were sold to the public [...]. Publisher and reader were connected in a new way, not just through the text of the works that the former published but also through the package in which the text appeared [...]. [The] binding could not only reflect a book's content or genre but in itself influence a customer's decision whether or not to purchase it. As a result, publishers devoted considerable attention and expense to the design and appearance of the binding. ${ }^{36}$

15 The rise of new formats and genres thus led to a new emphasis on the material qualities of the book, which effectively functioned as a form of commercial advertising. 
Janice Radway points out that the rise of mass literacy, larger print runs, and popular genres encouraged publishers to begin "contracting with a large pool of writers who wrote books regularly and respectively according to editorial specifications by drawing on well-known material already circulating in the press and on the popular stage. ${ }^{37}$ As a result, authorship was increasingly seen as an assembly-line process in which writers churned out standardized products as quickly as possible in order to meet production quotas. Mary Noel similarly notes that "demand [...] created a supply," as a new kind of low-class writer emerged who was willing to produce copy on demand for a minimal wage. In other words, this species of writer, commonly known as a "hack," was "as much a product of the Industrial Revolution as was the Hoe printing press." ${ }^{38}$ This new publishing system thus conceived of the book as a mass-produced commodity, of the author as an industrial laborer, and of the publishing industry as a capitalist enterprise designed to exploit workers in order to maximize profits.

Despite the increased availability of cheap editions, most new books still represented a significant investment, particularly for working-class readers. In the U.K., the average working-class reader had a weekly income of roughly 30 s, so a cheap single-volume reprint edition priced at $3 \mathrm{~s} 6 \mathrm{~d}$ might represent their entire disposable income for the week. Libraries thus became the easiest way to access books, yet subscription libraries in the U.K.

tended to have rather high annual subscriptions, they sometimes required subscribers to take a share in the library and they frequently concentrated on 'serious' subjects (theology, philosophy, history, biography, travel, etc.) to the exclusion or underrepresentation of fiction [...]. [W]ith the growing production and consumption of fiction-particularly in the form of the novel-such libraries were never going to satisfy what many would have regarded as a vulgar demand. This was left to commerce, and commerce was what circulating libraries were all about. ${ }^{39}$

The growth of popular reading thus led to the rise of commercial circulating libraries, which not only served poorer areas but also catered to the specific demands of workingclass readers, who overwhelmingly preferred to read popular genre fiction. These libraries became known as "twopenny libraries," which referred to the cost of borrowing a book, and they particularly specialized in western and romance novels. ${ }^{40}$

Similar developments took place in France, where librarians initially sought to direct the reading habits of working-class readers by limiting their holdings to canonical works of literature :

[L]ibrary reformers hoped that by providing suitable literature, and by encouraging the reading habit, they could soften social tensions. Working-class readers, it was hoped, could be weaned away from drink and from dangerous literature with tendencies towards socialism, excessive superstition or obscenity. A range of useful literature, to promote "rational recreation", would incorporate the more intelligent members of the working class into a consensus of bourgeois values. ${ }^{41}$

Working-class readers often rejected the kinds of books that were being offered, however, as they preferred popular novels instead. This led to the rise of "popular libraries," which were commercial businesses that catered specifically to the demands of working-class readers :

The popular reader, often patronizingly known as "le grand enfant," had a mind of his own. A lithographer, Girard, set up a bibliothèque populaire in the third arrondissement of 
Paris, and tried to evade municipal surveillance for as long as possible [...]. Two popular libraries had been set up in the industrial city of St Étienne in 1866, which the city notables and clerical élite attempted to bring under control [...]. [W]orking-class readers struggled to form their own literary culture, free of bourgeois, bureaucratic or Catholic control. 42

Similar developments took place in Germany, where some of these libraries became huge businesses. In Berlin, for example, the Borstell and Reimarus library offered 600,000 different titles in $1891 .^{43}$

The rise of a mass reading public that preferred to read popular novels, which the literary elite considered to be vulgar, immediately inspired fears of cultural degradation. As Cathy N. Davidson points out, the application of "Gresham's Law" to literary production was already prevalent in the nineteenth century :

[M]any people believed in a Gresham's law of texts or reading. Bad new works would supposedly drive out good old ones, so that a print world dominated by the Bible, The Day of Doom, sermons, tracts, and sundry other religious works well might be superseded by a new world of predominantly secular reading, of texts designed merely to amuse, not to instruct [...]. The novel threatened not just to coexist with elite literature, but to replace it. $^{44}$

Such fears were clearly expressed in Noah Porter's 1881 book on Books and Reading :

$[B]$ ad books and inferior books are far more common than they once were. Their poison is also more subtle and less easily detected, for as the taste of readers becomes omnivorous, it becomes less discriminating. Besides, the readiness with which good men, and men sturdy in their principles too, read books which they despise and abhor, has introduced a freedom of practice on this subject, at which other generations would have stood aghast. In many cases too, if the principles are not corrupted by reading, the taste is vitiated. Or if nothing worse happens, delicacy of appreciation suffers from the amount of intellectual food which is forced upon us, and the satisfaction is far less keen and exquisite than was enjoyed by readers of a few books of superior merit. ${ }^{45}$

Porter thus argued that the mass production of books results in an increase in the number of bad books being published, and the danger of these bad books is that they make it more difficult for readers to appreciate good books. In other words, the decline in literary taste was seen as a direct result of the industrialization of print.

Other critics argued that the degradation of culture was a result not only of the quantity of books being published but also the quality and price of the material book itself, which made it increasingly difficult to distinguish good books from bad ones. As a commentator wrote in the New York Evening Mail in 1880 :

When a book cost money it was something to be preserved with care, and guarded and cherished as a thing of value. Hence, the possession of handsome editions of good books was a matter of pride to their owners. [Today, however,] books, even of sterling value, are read and thrown away [...]. The publication which may be bought for a few pence, however worthy its contents, is likely to be regarded like a newspaper, as something to be skimmed over and for-gotten. ${ }^{46}$

American poet James Russell Lowell made a similar argument in 1893 :

The problem for the scholar was formerly how to acquire books; for us it is how to get rid of them. Instead of gathering, we must sift. ${ }^{47}$ 

circulating libraries was undoubtedly Q. D. Leavis' 1939 book Fiction and the Reading Public which argued that popular fiction represents a direct threat to highbrow literature: “ When Railway Libraries and Yellow Backs offered a kind of reading that needed little exertion, it was not likely that any other would stand a chance." ${ }^{52}$ Leavis' claim that popular reading is a "drug habit" 53 that makes readers incapable of intellectual exertion clearly echoes Lowell's argument that "it has supplanted a strenuous habit of thinking with a loose indolence of reading which relaxes the muscular fiber of the mind." Like Unwin, Leavis also saw the circulating libraries as the primary cause of this cultural degradation, as the reading public "buys its literature in accordance with tastes acquired from its circulating library reading." ${ }^{54}$ Circulating libraries direct the tastes of readers towards best-selling novels because this enables publishers to maximize profits, yet it effectively discourages the public from reading "anything which by the widest stretch could be included in the classification "literature." ${ }^{55}$ As a result, "the general public [...] has now not even a glimpse of the living interests of modern literature, is ignorant of its growth and so prevented from developing with it." ${ }^{56}$ According to Leavis, therefore, circulating libraries do not promote literacy by providing access to print material, but rather they actively discourage literacy by threatening the literary establishment : "[T]he critical minority to whose sole charge modern literature has now fallen is isolated, disowned by the general public and threatened with extinction." ${ }^{57}$

Pierre Bourdieu provides a sociological explanation for these fears by explaining how popular fiction and "pure" literature were gradually seen as two competing modes of production :

These fields are the site of the antagonistic coexistence of two modes of production and circulation obeying inverse logics. At one pole, there is the anti-"economic" economy of pure art. Founded on the obligatory recognition of the values of disinterestedness and on the denegation of the "economy" (of the "commercial") and of "economic" profit (in the short term), it privileges production [...] oriented to the accumulation of symbolic capital, 
a kind of "economic" capital denied but recognized, and hence legitimate [...]. At the other pole, there is the "economic" logic of the literary and artistic industries which, since they make the trade in cultural goods just another trade, confer priority on distribution, on immediate and temporary success, measured for example by the print run, and which are content to adjust themselves to the pre-existing demand of a clientele [...]. An enterprise moves closer to the "commercial" pole the more directly or completely the products it offers on the market respond to a pre-existing demand, and in pre-established forms. ${ }^{58}$

31 Like Leavis, therefore, Bourdieu argues that popular fiction was seen as a commodity that could be standardized and mass produced in order to maximize profits, while literary fiction was based on a rejection of economic profit and an accumulation of "symbolic capital" or prestige. This cultural shift helps to explain why publishers did not market literary novels in the same way as popular novels, as Ellen Gruber Garvey points out :

Too frankly acknowledging commodity status threatened the prestige that old-line publishers considered essential to success. Prestige could not be bought outright ; it could only be traded or invested for greater prestige [...]. Prestige differentiated the products of old-line publishers from the cheap editions [...] of publishers who advertised in posters, eye-catching window displays, and newspaper ads..$^{59}$

Unlike Leavis, however, Bourdieu argues that the rise of popular fiction does not represent a threat to "pure" literature, as the "symbolic capital" of literature depends on its rejection of commercialism. The rise of a mass readership also poses no threat to the literary establishment, according to Bourdieu, as the divide between working-class readers and the literary elite represents the very source of this minority's privileged status as defenders of culture. Bourdieu notes, for example, that this new definition of literature did not emerge until after the literary establishment had already consolidated its social power through the founding of non-profit institutions dedicated to the conservation, interpretation, and celebration of "pure" literature..$^{60}$ In other words, publishers generate economic value through the mass production and distribution of popular fiction, while the literary elite generate symbolic value by rejecting the economic imperatives that drive the publishing industry.

Bourdieu's argument is certainly compelling, yet it is important to note that publishers also attempted to exploit the symbolic value of books through the production of deluxe editions. Already at the end of the eighteenth century, Cotta published the collected works of Wieland in four different formats, thus offering an enormous range of options for the acquisition of the always identical text. ${ }^{61}$ In 1854 George Putnam similarly offered an edition of Irving's works in seven different types of prestige bindings : cloth (\$19), sheep ( $\$ 20)$, half calf $(\$ 30)$, half morocco, gilt tops (\$33), calf, extra (\$37.50), calf, antique (\$40), and morocco, super extra (\$48). As Ronald Zobray points out, "innovations in bookbinding created a market for books with elaborate bindings as expensive luxury commodities." 62 For many readers, therefore, the appearance of a book mattered as much, if not more, than its content: The conspicuous consumption of books during the era meant that some readers preferred owning books over reading them." ${ }^{63}$ David McKitterick makes a similar point concerning the use of gold-blocking: "The discovery that [cloth] could be gold-blocked led to some of the greatest changes in the appearance of bindings-and, hence, in the ways that books could be publicised and presented to potential readers [...]. Books could be sold almost as much by their outside as by their contents." ${ }^{64}$ Radway adds that this emphasis on the appearance of books also reflects the 
notion of literature as commodity, as the economic value of the material form of a book became synonymous with the symbolic value of its content:

In this more traditional discourse the book was conceived of [...] as a permanent and precious possession. Characterized concurrently as a kind of verbal real estate, this book was considered intellectual or cultural property. Since its intrinsic value was understood to increase with age [...] it required a design that would promote longevity ; hence the need for high-quality paper, secure bindings, and hard covers. ${ }^{65}$

Through the logic of property, the cultural value of the book could also enhance the cultural status of its owners:

Potentially, then, every book sale could generate two forms of profit. On one hand it could generate cash for its publishers. On the other hand it could also produce perceived changes in the status of the individual who bought it because the more traditional discourse about the book had managed to associate the social prestige of learning with the particular technology for producing that learning in the first place, that is, with the leather- or cloth-covered book itself. ${ }^{66}$ Mary Benton employs the term "bookaflage" to describe the practice of purchasing and exhibiting certain editions for the purpose of constructing a "cultural persona": "Books played a prominent, often featured role in the widespread preoccupation with fashioning one's domestic environment, which in turn suggested-and presumably shaped-one's very persona [...]. One's books could be selected and arranged to present whatever impression one wished to make, be it literary delicacy, friendly charm, or erudite intellect." ${ }^{77}$ This practice also explains why books appeared in nearly 30 percent of magazine advertisements, where they were used as "props or part of the background scene to telegraph implicit messages about the intelligence, social class, and personal values of the depicted subject," and these values were not conveyed through titles or authors but rather through "heft, dimensions, and often a subdued, elegant binding." 68

Jeffrey D. Groves points out that certain bindings also became associated with certain publishers :

[A] house style [...] communicated a message of literary quality : if some of the books brought out by a publisher achieved canonical status, and the external design of most of the publisher's books looked identical, then the intended message from producer to consumer seems to have been that, like their appearance, the quality of the publisher's book was consistent. Moreover, the development of house styles as texts for communicating such value judgments was historically concurrent with publishers' increasing sophistication in literary promotion, and the synthesis of book design and promotion encouraged consumers to read bindings as guarantors that literary quality awaited within. ${ }^{69}$

These house styles thus "presented a prestigious spine to the world and so could function as status statements on a bookshelf." 70 The brown cover of Ticknor and Fields' books, for example, "came to suggest gravity, elegance, and good taste." ${ }^{71}$ Rather than seeing the book as a disposable commodity, therefore, the production of deluxe editions shows that books also served as markers of a reader's socioeconomic status-regardless of whether or not the books were actually read. By serving as markers of distinction, the material book can thus be seen as a reification of social relations, much like fashion or home décor. ${ }^{72}$ The sense of distinction embodied in the material book represents "another form of the 
visceral disgust at vulgarity which defines pure taste as an internalized social relationship, a social relationship made flesh." ${ }^{73}$

In recent years, Franco Moretti has published several insightful studies combining abstract models for literary history with large, complex, and mostly diachronic data analyses, which have served as examples for many others. ${ }^{74}$ His contributions are especially interesting for setting up the criterion of "literary success" for certain titles or genres. According to the articles collected in this issue of Belphégor, commercial success is related to taste and cultural prestige; they are transmitted through the materiality of literary texts as printed books that circulate in specific ways. Despite its many merits, Moretti's approach neglects such material aspects, ${ }^{75}$ as it makes no clear distinction between texts and books. The essays collected here thus attempt to analyze the tension between literary fiction and popular fiction via the relationship between the material properties of books and their cultural prestige, as the commercial success of a book is distinguished from its general commercial success as a text.

The first contribution in this issue of Belphégor, Jennifer Tsien's “Diderot's Battle against Books: Books as Objects during the Enlightenment and Revolution," provides a perfect starting point for this discussion by examining the book debates that immediately preceded the "reading revolution" of the nineteenth century. Tsien's research also challenges the popular assumptions that Enlightenment thinkers had always advocated education for all and that they believed education necessarily required literacy and access to books. Tsien argues that this optimistic vision of the Enlightenment reflects our own contemporary desire to see a linear progression from the eighteenth century to the French Revolution and ultimately to the Republican values of present-day France. However, Diderot and his fellow philosophes did not set out to democratize knowledge. Instead, the rise of literacy alarmed them, and they denounced both the quantity of books in circulation and the people's enthusiasm for them. Diderot, for example, described ways of reading, interpreting, and collecting books that depended on a distinction between the savants (such as himself) and ordinary readers. In his view, only a few people deserved to have books, and only a few books deserved to be printed. Diderot also argued that books were meant not to be idolized but to be circulated. In all of these areas, the essential distinction that Diderot makes is between, on the one hand, books as objects that people want to possess for their monetary value or their cultural prestige and, on the other hand, books as useful objects or tools that allow experts to produce more books. Ultimately, he champions the latter use of books and even declares them to be disposable once they have served their purpose-a shocking idea that was ultimately put to the test during the French Revolution.

Kate Roy's "Only the 'Outward Appearance' of a Harem? Reading the Memoirs of an Arabian Princess as Material Text" examines the material properties of various editions of Emily Ruete's Memoirs of an Arabian Princess from the 1886 to the present. Emily Ruete (born Sayyida Salme) was the daughter of the Sultan of Oman and Zanzibar, and her memoir is considered the oldest published autobiography written by an Arab woman. The book has since gone through numerous editions, which have presented the work as either an important historical document concerning the life of Arab women or an erotic romance that plays on the exotic elements of the harem narrative. Roy examines how the tension between these competing versions of Ruete's memoir is staged through the material properties of the texts, including the format, binding, cover, paper stock, and price. Roy particularly focuses on how these properties perform a sort of cultural translation for 
different audiences over time. For example, the persistence of the original frontispiece image of an Arab woman in a veil as lead-in to modern fictionalizations of the memoir often serves to conflate the genres of the autobiography and the novel. Ruete's memoir has even been transformed into a Victorian erotica Kindle ebook titled Dangerous Romance , which incorporates various soft porn images of Arab women. Roy argues that this extreme genre confusion could only be the result of a superficial engagement with the material properties of the original text, which illustrates how the reception of this book has largely been guided by its materiality.

41 In "Der Druck der Phantasmen: Di Illustrationen des Feuilletonromans des 19. Jahrhunderts und ihre Aneignung in Max Ernsts Collageroman Une Semaine de Bonté" Philipp Venghaus examines how Ernst's 1934 collage novel incorporates illustrations taken from nineteenth-century roman-feuilleton in order to deconstruct this popular genre. These serialized novels traditionally included extensive illustrations, which helped readers to visualize the narratives, yet in Ernst's work these illustrations are transformed in ways that defy any straightforward critical interpretation. Instead of representing the real world, they more often appear to represent the fantastic or mythical landscape of dreams and the unconscious. The illustrations from roman-feuilleton are also juxtaposed with images from medical and criminological textbooks, which are used to classify various forms of abnormalities or monstrosities. By alluding to the abnormal and by disfiguring these images even further through the form of the collage itself, Ernst's novel effectively subverts the formal structure of the text and establishes a magical connection that directly opposes rational ways of seeing the world. The collage novel is thus regarded as an abnormality or a mutation that cannot be understood solely through reason or intellect. Une Semaine de Bonté likewise becomes a true and pure work of art through economic distinctions of rarity and sales price.

Anthony Enns' "The Poet of the Pulps: Ray Bradbury and the Struggle for Prestige in Postwar Science Fiction" examines how the rise of digest magazines and paperback novels transformed the cultural status of science fiction in the U.S. in the mid-twentieth century, as the genre began to appeal to a wider readership and was reviewed in mainstream literary publications. The notion of science fiction as a legitimate literary genre was thus inherently linked to the emergence of new material forms, which appealed to a broader range of taste cultures. In order to examine this cultural shift, Enns focuses specifically on the publication history of Ray Bradbury's 1953 novel Fahrenheit 451. This novel illustrates the cultural transformation of science fiction not only because it was one of the first magazine stories expanded and republished as a novel, but also because it was one of the first science fiction novels to achieve significant recognition among mainstream critics. The desire for cultural legitimacy is also mirrored within the narrative itself, as it illustrates the perceived threat mass culture posed to the literary establishment, which has encouraged some critics to interpret the novel as an attempt to preserve the power of the literary elite. Enns complicates this reading, however, by pointing out that Bradbury was simultaneously involved in the production of many different forms of mass culture, including comic books, films, radio, and television. Furthermore, the novel's condemnation of book burning directly targeted the morality campaigns of the late 1940s and early 1950s, which sought to protect the nation's youth from the evils of mass culture. A closer examination of the publication history of Fahrenheit 451 thus reveals how it was designed to appeal to a wide range of taste cultures, which complicates the notion that it is simply an elitist text that critiques the rise of mass 
culture and endorses the same cultural values that informed mid-twentieth century morality campaigns.

43 An Goris' "Hidden Codes of Love:The materiality of the Category Romance Novel" examines the significance of the material properties of romance novels. While their homogeneous appearance is often seen as a reflection of their low cultural status, Goris argues that the material elements of these novels also reflect dual semiotic codes that challenge their perceived homogeneity. On the one hand, their packaging features a large number of semiotic signs that clearly identify the book as belonging to the romance genre, such as the cover image of the passionate couple and the publisher's logo. On the other hand, these elements also contain signs that denote the existence of heterogeneity within the generic group. For example, each individual version of the cover image contains a host of other signs that denote variations upon the basic generic pattern, as it conveys information about each novel's subgenre, sexual explicitness, and date of publication. Goris' analysis reveals a similar dynamic in most of the romance novel's material properties, which shows how these features represent a complex semiotic system that seeks to appeal exclusively to the romance novel's target readership and to ward off all other readers. It is primarily through the material properties of the text, in other words, that the genre and its readership are identified and circumscribed.

In "Mutation des supports, mutation des publics. La bande dessinée de la presse au livre" Sylvain Lesage focuses on the history of comic strips and graphic novels in France and Belgium. He begins by examining the cultural and editorial changes that made the bande dessinée central to contemporary French culture. The crucial point for this reevaluation was the change from comics in high print runs in cheap comic journals to lower print runs in more expensive books in the album format, which unified a previously published series into one book-like volume. Lesage also examines how lending rates and book sales have encouraged more and more highbrow publishers in recent years to publish work in this formerly shady genre. This change has been made possible through the transfer of the "sacral" features of the book into the vulgar realm of the comic strip. The importance of the bookish features of bande dessinée can also be seen in the biases of comic festivals and the purchasing policies of libraries or museums, which have also contributed to the new cultural legitimacy of comic strips and graphic novels. This cultural legitimacy has not only been economically successful, but it has also led to the establishment of "the ninth art" in the field of art history, as many of the creators of comic strips have been elevated to the status of artists. Through a change in the material properties of texts, a formerly detested popular genre consisting of violence, sex, and crime has thus become part of highbrow culture.

Giovanni Remonato's "Corto Maltese tra fumetto e letteratura disegnata" examines the publication history of Hugo Pratt's Corto Maltese comics in order to examine the relationship between its various editions and its cultural prestige. At the time of its first appearance in 1967, this series was published in comic magazines for children, such as Il Corriere dei Piccoli in Italy and Pif Gadget in France. It then moved to a new type of adultoriented magazine with more intellectual ambitions, such as Linus. In 1973 it was republished in book form by Mondadori, a major Italian publishing house, and in 1995 it was even transformed into a novel. By examining various editions of the text, Remonato thus traces the rise of this series from children's fiction to highbrow culture. This includes the ambitions of its creator, as Pratt aims to create "letteratura disegnata" or "drawn literature," while at the same time being an advocate (and consumer) of the 
popular arts and refusing to be called an "artist." The cultural prestige that Corto Maltese has achieved is also confirmed by other material instantiations of the series outside the realm of comics, including film adaptations and museum exhibitions, as well as translations into different languages.

Thorsten Bothe's "Stephen Kings Das Mädchen (Schneekluth Verlag)-Eine rhetorische Lektüre des Schutzumschlags" focuses on the cover of the German translation of Stephen King's The Girl Who Loved Tom Gordon, which was published in 2004 in two distinct versions with different ISBN numbers. Bothe argues that these two covers offer two conflicting interpretations that are virtually impossible to reconcile: black or white, life or death, hope or despair exclude each other and are triggered only by the dust jacket, as the binding, paper stock, and even cover price are all the same. Das Mädchen thus offers one of the rare opportunities to discuss one isolated paratextual distinction as a distinction of taste in a strict ceteris paribus manner. Bothe delivers a rich theoretical overview, covering rhetorical, mnemonic, and semiotic operations and options to deal with the dust jacket, which provides good reasons for judging books-or at least this particular bookby its cover. Bothe also shows that the choice between dust jackets ultimately grounds taste in distinctions that are impossible to explain. What is truly undecidable can only be resolved by a decision for one option or the other, and such a choice transports the reader into the realm of luxury, transgression, and art or even l'art pour l'art-concepts that are not easily related to the novels of Stephen King.

Jeff Thoss' “From Penny Dreadful to Graphic Novel: Alan Moore and Kevin O'Neill's Genealogy of Comics in The League of Extraordinary Gentlemen" examines how this contemporary comic book reflects both the late-Victorian media landscape from which comics first emerged as well as the current state of the medium in the early twenty-first century. The League of Extraordinary Gentlemen relates the adventures of a superhero team composed of characters from classic nineteenth-century literary texts, such as Allan Quatermain from H. Rider Haggard's King Solomon's Mines (1885) and Mina Murray from Bram Stoker's Dracula (1897), who battle classic nineteenth-century villains, such as Sherlock Holmes's archenemy Professor Moriarty or the Martian invaders from H. G. Wells' The War of the Worlds (1898). The League of Extraordinary Gentlemen also includes visual references to obscure nineteenth-century popular texts, including Victorian illustrated newspapers, penny dreadfuls, and boys' weeklies. On the one hand, Thoss argues that these intertextual references challenge the divisions between high and low culture, as they blur the boundaries between classic works of literature and ephemeral works of popular fiction. The League of Extraordinary Gentlemen can thus be seen as a reaction against the contemporary trend to praise the "graphic novel" as a sign of the genre's evolution into a more serious artform. On the other hand, Thoss argues that these allusions to Victorian popular culture also serve as a "hallmark of sophistication," which suggests that in some ways The League of Extraordinary Gentlemen is a textbook example of an ambitious and demanding comic that appears to be written for authors, editors, students, and professors-in other words, for readers who would not otherwise buy comics. The publication of supplemental guidebooks further illustrates the complexity of this series and the need for readers with scholarly training, and the publication of expensive deluxe editions also encourages the perception of the comic as a serious work of literature. The material properties of the text thus reflect the contested status of the genre as a whole. 
Although they cover a wide range of historical periods and genres-from Enlightenment philosophy to contemporary comics-all of the contributions in this issue reflect a common set of concerns involving the relationship between prestige and materiality, as distinctions of taste are ultimately embodied in or even determined by the material properties of texts. Many of these contributions also address the larger cultural significance of these distinctions, as books that are perceived as valuable are fetishized for their appearance as much as their content. In other words, literary texts serve a crucial non-literary function as markers of socioeconomic status, regardless of whether or not they are actually read. Material distinctions are therefore not restricted to the past; rather, they are more relevant now than ever before. Today, first editions are usually only published in one binding type, but as soon as they are republished the number of available covers and binding types rapidly increases. The simultaneous publication of a text as both a print book and an ebook also raises questions concerning material distinctions. The same holds true for the migration of texts between languages and cultures, as a text that was originally published as lowbrow fiction could easily become highbrow literature in translation through the acquisition of a new publisher and a new material form, and vice versa. The incorporation of illustrations also has the potential to transform the cultural status of a text by turning it into a work of children's fiction or an objet d'art, depending on the material properties of the text and the reputation of the illustrator. The method of distribution-through prestigious bookstores, railway bookstalls, mail-order catalogs, book clubs, or newspaper giveaways-also clearly influences the cultural prestige of a text. ${ }^{76}$

The sociological function of literature has encouraged the notion that books without value should simply be discarded or even burned-an idea that was actively promoted during the Enlightenment and was later justified by the inferior material qualities of popular texts, as seen in the case of mid-twentieth century American morality campaigns. The relationship between prestige and materiality in the realm of literature thus reflects fundamental historical changes with regard to the development of technology, literacy, and social power. While the industrialization of print resulted in a sudden explosion of print material, which democratized literature by making books available to a mass reading public, these developments were perceived as a potential threat to the literary elite, who relied on material distinctions as a way of securing their cultural authority. As Bourdieu emphasizes, however, the anti-economic logic underlying their concept of "pure" literature was, in truth, only a rejection of economic profit "in the short term." Bourdieu thus implies that the literary establishment has never truly rejected the idea of economic profit; rather, it was simply committed to literature as a long-term financial investment. In the end, therefore, the circulation of "symbolic capital" is indelibly linked to the circulation of actual capital, as money generates prestige and prestige generates money. Literature as one of its specific forms, makes no distinction here, or at least no distinction that wouldn't matter. 


\section{BIBLIOGRAPHY}

Badaracco, Claire Hoertz. Trading Words: Poetry, Typography, and Illustrated Books in the Modern Literary Economy. Baltimore: Johns Hopkins University Press, 1995.

Benton, Megan. “'Too Many Books': Book Ownership and Cultural Identity in the 1920s.” American Quarterly 49.2 (1997): 268-297.

Benton, Megan. "Unruly Servants: Machines, Modernity, and the Printed Page." A History of the Book in America. Ed. Carl F. Kaestle and Janice Radway. 5 vols. Chapel Hill: University of North Carolina Press, 2009. 4: 151-169.

Bode, Dietrich, ed. Reclam. 125 Jahre Universal-Bibliothek 1867-1992. Stuttgart : Reclam, 1992.

Bose, Günter Karl. Das Ende einer Last. Die Befreiung von den Büchern. Göttingen: Wallstein, 2013.

Bosse, Heinrich. Autorschaft ist Werkherrschaft : Über die Entstehung des Urheberrechts aus dem Geist der Goethezeit. Paderborn : Schöningh, 1981.

Bourdieu, Pierre. Distinction: A Social Critique of the Judgement of Taste. Trans. Richard Nice.

Cambridge: Harvard University Press, 1984.

Bourdieu, Pierre. The Rules of Art: Genesis and Structure of the Literary Field. Trans. Susan Emanuel. Stanford: Stanford University Press, 1995.

Cahn, Michael. “Opera Omnia: The Production of Cultural Authority." History of Science, History of Text. Ed. Karine Chemla. Dordrecht: Springer, 2004. 81-94.

Colclough, Stephen. "Distribution." The Cambridge History of the Book in Britain. Ed. John Barnard, D. F. McKenzie, David McKitterick, and I. R. Willison. 7 vols. Cambridge: Cambridge University Press, 1998. 6: 238-280.

Dahl, Svend. History of the Book. New York: Scarecrow Press, 1958.

Davidson, Cathy N. Revolution and the Word: The Rise of the Novel in America. Oxford: Oxford University Press, 1986.

Davidson, Cathy N. “Towards a History of Books and Readers.” American Quarterly 40.1 (1988): 7-17.

Dumasy, Lise. La querelle du roman-feuilleton. Littérature, presse et politique, un débat précurseur (1836-1848). Grenoble: Éditions littéraires et linguistiques de l'Université de Grenoble, 1999.

Eliot, Simon. "Circulating Libraries in the Victorian Age and After." The Cambridge History of Libraries in Britain and Ireland. Ed. Peter Hoare. 3 vols. Cambridge: Cambridge University Press, 2006. 3: 125-146.

Eliot, Simon and Nash, Andrew. "Mass Markets: Literature." The Cambridge History of the Book in Britain. Ed. John Barnard, D. F. McKenzie, David McKitterick, and I. R. Willison. 7 vols. Cambridge: Cambridge University Press, 1998. 6: 416-442.

Engelsing, Rolf. Analphabetentum und Lektüre : Zur Sozialgeschichte des Lesens in Deutschland zwischen feudaler und industrieller Gesellschaft. Stuttgart: Metzler, 1973. 
Engelsing, Rolf. Der Bürger als Leser: Lesergeschichte in Deutschland 1500-1800. Stuttgart: Metzler, 1974.

Engelsing, Rolf and Erlin, Matt. "How to Think About Luxury Editions in Late Eighteenth- and Early Nineteenth-Century Germany." Publishing Culture and the "Reading Nation": German Book History in the Long Nineteenth Century. Ed. Lynne Tatlock. Rochester: Camden House, 2010. 25-54.

Feather, John P. "The Book in History and the History of the Book." The History of Books and Libraries: Two Views. Ed. John P. Feather and David McKitterick. Washington, DC: Library of Congress, 1986. 1-16.

Fischer, Steven Roger. A History of Reading. London: Reaktion Books, 2003.

Gruber Garvey, Ellen. "Ambivalent Advertising: Books, Prestige, and the Circulation of Publicity." A History of the Book in America. Ed. Carl F. Kaestle and Janice Radway. 5 vols. Chapel Hill: University of North Carolina Press, 2009. 4: 170-189.

Groves, Jeffrey D. "Judging Literary Books by Their Covers: House Styles, Ticknor and Fields, and Literary Promotion." Reading Books: Essays on the Material Text and Literature in America. Ed. Michele Moylan and Lane Stiles. Amherst: University of Massachusetts Press, 1996. 75-100.

Law, Graham, and Patten, Robert L.. "The Serial Revolution." The Cambridge History of the Book in Britain. Ed. John Barnard, D. F. McKenzie, David McKitterick, and I. R. Willison. 7 vols. Cambridge: Cambridge University Press, 1998. 6: 144-171.

Leavis, Q. D. Fiction and the Reading Public. London: Chatto and Windus, 1939.

Lowell, James Russell. The Function of the Poet and Other Essays. Boston: Houghton Mifflin, 1920.

Lyons, Martyn. "Les best-sellers." Histoire de l'édition française. Ed. Henri-Jean Martin, Roger Chartier, and Jean-Pierre Vivet. Paris: Promodis, 1985. 3: 369-377 and 382-397.

Lyons, Martyn. "New Readers in the Nineteenth Century: Women, Children, Workers." A History of Reading in the West. Ed. Guglielmo Cavallo and Roger Chartier. Trans. Lydia G. Cochrane. Amherst: University of Massachusetts Press, 1999. 313-344.

Lyons, Martyn. A History of Reading and Writing in the Western World. New York: Palgrave Macmillan, 2010.

Mazal, Otto. Einbandkunde. Die Geschichte des Bucheinbandes. Wiesbaden : Reichert, 1997.

McAleer, Joseph. Popular Reading and Publishing in Britain, 1914-1950. Oxford: Clarendon Press, 1992.

McKitterick, David. "Changes in the Look of the Book." The Cambridge History of the Book in Britain. Ed. John Barnard, D. F. McKenzie, David McKitterick, and I. R. Willison. 7 vols. Cambridge: Cambridge University Press, 1998. 6: 75-116.

McKitterick, David. "Introduction." The Cambridge History of the Book in Britain. Ed. John Barnard, D. F. McKenzie, David McKitterick, and I. R. Willison. 7 vols. (Cambridge: Cambridge University Press, 1998). 6: 1-74.

Metz, Bernhard. "Bibliomania and the Folly of Reading." Comparative Critical Studies 5.2 (2008): 249-269.

Michelson, Bruce. Printer's Devil: Mark Twain and the American Publishing Revolution. Berkeley: University of California Press, 2006.

Mollier, Jean-Yves, and Cachin, Marie-Françoise. “A Continent of Texts: Europe 1800-1890.” A Companion to the History of the Book. Ed. Simon Eliot and Jonathan Rose. Oxford: Blackwell, 2007. 303-314. 
Moretti, Franco. Graphs, Maps, Trees: Abstract Models for a Literary History. London: Verso, 2005.

Moretti, Franco. "Critical Apparatus: The Market for Novels-Some Statistical Profiles." The Novel. Ed. Franco Moretti. 2 vols. Princeton: Princeton University Press, 2006, 1: 427-530.

Moretti, Franco. Distant Reading. London: Verso, 2013.

Morison, Stanley. Memorandum on a Proposal to Revise the Typography of 'The Times'. London: The Times, 1930.

Morison, Stanley. Supplement to the Memorandum. London: The Times, 1931.

Mosley, James. "The Technologies of Printing." The Cambridge History of the Book in Britain. Ed. John Barnard, D. F. McKenzie, David McKitterick, and I. R. Willison. 7 vols. Cambridge: Cambridge University Press, 2009. 5: 163-199.

Nash, Andrew. "Literary Culture and Literary Publishing in Inter-war Britain." Literary Cultures and the Material Book. Ed. Simon Eliot, Andrew Nash, and Ian Willison. London: British Library, 2007. 323-342.

Neumann, Peter. "Herstellungstechnik und Buchgestaltung. Industrielle Buchproduktion. Buchgestaltung." Geschichte des Deutschen Buchhandels im 19. und 20. Jahrhundert. Bd. 1.1: Das Kaiserreich 1870-1918. Ed. Georg Jäger. Frankfurt : Buchhändler-Vereinigung and MVB Marketingund Verlagsservice des Buchhandels, 2001. 170-196.

Noel, Mary. Villains Galore: The Heyday of the Popular Story Weekly. New York: Macmillan, 1954.

Porter, Noah. Books and Reading. New York: Scribner's, 1881.

Queffélec, Lise. Le roman-feuilleton français au XIX siècle. Paris: Presses Universitaires de France, 1989.

Radway, Janice A. A Feeling for Books: The Book-of-the-Month Club, Literary Taste, and Middle-Class Desire. Chapel Hill: University of North Carolina Press, 1997.

Rautenberg, Ursula. "Das Buch in der Alltagskultur. Eine Annäherung an zeichenhaften Buchgebrauch und die Medialität des Buches." Buchkulturen. Beiträge zur Geschichte der Literaturvermittlung. Festschrift für Reinhard Wittmann. Ed. Monika Estermann, Ernst Fischer, and Ute Schneider. Wiesbaden : Harrassowitz, 2005. 487-516.

Robak, Brigitte. "Schriftsetzerin. Ein Beruf für Frauen. Pariser Projekt aus der Revolutionszeit." Journal Geschichte 2-3 (1991): 18-27.

Robak, Brigitte. Vom Pianotyp zur Zeilensetzmaschine. Setzmaschinenentwicklung und Geschlechterfrage 1840-1900. Marburg : Jonas, 1996.

Schön, Erich. Der Verlust der Sinnlichkeit oder die Verwandlung des Lesers. Mentalitätswandel um 1800. Stuttgart: Cotta, 1987.

Senefelder, Alois. Vollständiges Lehrbuch der Steindruckerey enthaltend eine richtige und deutliche Anweisung zu den verschiedenen Manipulations-Arten derselben in allen ihren Zweigen und Manieren belegt mit den nöthigen Musterblättern nebst einer vorangehenden ausführlichen Geschichte dieser Kunst von ihrem Entstehen bis auf gegenwärtige Zeit. München : Thienemann, 1818.

Sonn, William J. Paradigms Lost: The Life and Deaths of the Printed Word. Lanham, MD: Scarecrow Press, 2006.

Tebbel, John William. A History of Book Publishing in the United States. 4 vols. New York: R. R. Bowker, 1975. 
Tsien, Jennifer. The Bad Taste of Others: Judging Literary Value in Eighteenth-Century France. Philadelphia: University of Pennsylvania Press, 2012.

Twyman, Michael. “The Illustration Revolution.” The Cambridge History of the Book in Britain. Ed. John Barnard, D. F. McKenzie, David McKitterick, and I. R. Willison. 7 vols. Cambridge: Cambridge University Press, 1998. 6: 117-143.

West, James L. W. III. "The Expansion of the National Book Trade System.” A History of the Book in America. Ed. Carl F. Kaestle and Janice Radway. 5 vols. Chapel Hill: University of North Carolina Press, 2009. 4: 78-89.

Winship, Michael. "Manufacturing and Book Production." A History of the Book in America, Volume 3: The Industrial Book 1840-1880. Ed. Scott E. Casper, Jeffrey D. Groves, Stephen W. Nissenbaum, and Michael Winship. Chapel Hill: University of North Carolina Press, 2007. 40-69.

Wittmann, Reinhard. Geschichte des deutschen Buchhandels. Ein Überblick. München: C.H. Beck, 1991.

Zboray, Ronald J. “Antebellum Reading and the Ironies of Technological Innovation.” American Quarterly 40.1 (1988): 65-82.

Zboray, Ronald J. A Fictive People: Antebellum Economic Development and the American Reading Public. Oxford: Oxford University Press, 1993.

\section{NOTES}

1. See, for example, Jennifer Tsien, The Bad Taste of Others: Judging Literary Value in EighteenthCentury France (Philadelphia : University of Pennsylvania Press, 2012).

2. This development took approximately twenty to thirty years in all parts of this worldwide business, as David McKitterick writes concerning the U.K.: "For decades after 1800, books, periodicals, newspapers and all kinds of minor works continued to be set by hand, with type cast by hand, and printed by means of hand-presses.... But nevertheless, by about 1830 some of the major changes in manufacture, materials, market demands and economic possibilities had become sufficiently widespread for it to be possible to claim that a revolution of some kind had been effected." (David McKitterick, "Introduction", The Cambridge History of the Book in Britain, ed. John Barnard, D. F. McKenzie, David McKitterick, and I. R. Willison, 7 vols. [Cambridge: Cambridge University Press, 1998], $6: 3$ )

3. David McKitterick, "Changes in the Look of the Book", The Cambridge History of the Book in Britain, ed. John Barnard, D. F. McKenzie, David McKitterick and I. R. Willison, 7 vols. (Cambridge : Cambridge University Press, 1998), 6 : 93.

4. Megan Benton, "Unruly Servants : Machines, Modernity, and the Printed Page", A History of the Book in America, ed. Carl F. Kaestle and Janice Radway, 5 vols. (Chapel Hill: University of North Carolina Press, 2009), 4: 154. The literary text most relevant to these developments is Balzac's Illusions perdues (1837-43) with David Séchard inventing a reed-based paper. For more on the connections between authorship, copyright, and paper production, see Heinrich Bosse, Autorschaft ist Werkherrschaft: Über die Entstehung des Urheberrechts aus dem Geist der Goethezeit (Paderborn : Schöningh, 1981).

5. McKitterick, "Changes in the Look of the Book", 95.

6. For a famous comparison of the traditional wooden press, the Stanhope press, and subsequent changes in the printing business, see the opening pages of Balzac's Illusions perdues.

7. Ronald J. Zboray, A Fictive People: Antebellum Economic Development and the American Reading Public (Oxford: Oxford University Press, 1993), 11. For more on these developments, see the numerous articles in volumes II and III of A History of the Book in America, ed. David D. Hall (Chapel 
Hill: University of North Carolina Press, 2007 and 2010), volumes V and VI of The Cambridge History of the Book in Britain, ed. John Barnard, D. F. McKenzie, David McKitterick, and I. R. Willison (Cambridge: Cambridge University Press, 1998), volumes II, III, and IV of the Histoire de l'édition française, ed. Henri-Jean Martin, Roger Chartier, and Jean-Pierre Vivet (Paris: Promodis, 1984-1986), and Peter Neumann, "Herstellungstechnik und Buchgestaltung", Geschichte des Deutschen Buchhandels im 19. und 20. Jahrhundert. Bd. 1.1: Das Kaiserreich 1870-1918, ed. Georg Jäger (Frankfurt : Buchhändler-Vereinigung and MVB Marketing- und Verlagsservice des Buchhandels, 2001), 170-196.

8. Otto Mazal sees a relationship between the emergence of publisher's bindings and decorative luxury in post-revolutionary France (and other European countries as well), which influenced the aesthetics of traditional book binding: "Die Tendenz, die Buchdeckel immer reicher mit Schmuck $\mathrm{zu}$ versehen, ging von den ab etwa 1830 immer zahlreicher werdenden und auf den Markt kommenden französischen Verlegereinbänden aus. Um eine große Käuferschicht anzusprechen, suchte man den Effekt: die Bücher mußten teuer aussehen, ohne teuer zu sein. Daher waren großflächige goldene Plattenpressungen beliebt. In Anlehnung an den Ledermosaikeinband kam auch die Farbe hinzu. Die Handbuchbinder, die der immer stärker werdenden Konkurrenz des industriell gefertigten Verlegereinbandes gegenüberstanden, machten in ihrer Mehrzahl bei der zunehmenden Füllung der Einbandflächen mit." (Otto Mazal, Einbandkunde. Die Geschichte des Bucheinbandes [Wiesbaden : Reichert, 1997], 289)

9. See Alois Senefelder, Vollständiges Lehrbuch der Steindruckerey enthaltend eine richtige und deutliche Anweisung $z u$ den verschiedenen Manipulations-Arten derselben in allen ihren Zweigen und Manieren belegt mit den nöthigen Musterblättern nebst einer vorangehenden ausführlichen Geschichte dieser Kunst von ihrem Entstehen bis auf gegenwärtige Zeit (München: Thienemann, 1818).

10. Michael Twyman, "The Illustration Revolution", The Cambridge History of the Book in Britain, ed. John Barnard, D. F. McKenzie, David McKitterick, and I. R. Willison, 7 vols. (Cambridge : Cambridge University Press, 1998), $6: 143$.

11. For more on the rise of women typesetters in France, see Brigitte Robak, "Schriftsetzerin-Ein Beruf für Frauen. Pariser Projekt aus der Revolutionszeit", Journal Geschichte 2-3 (1991): 18-27. For more on the rise of women typesetters in Germany, see Brigitte Robak, Vom Pianotyp zur Zeilensetzmaschine. Setzmaschinenentwicklung und Geschlechterfrage 1840-1900 (Marburg: Jonas, 1996). For more on the rise of women typesetters in the U.S., see Zboray, A Fictive People, 6-11.

12. The nineteenth century was full of (often unsuccessful) mechanical typesetting machines, since typesetting was the bottle neck of the printing industry until the introduction of the Linotype and Monotype systems. Writers also became involved in this business. For example, the famous nineteenth-century American writer Samuel Clemens was closely involved in the development of the so-called "Paige Compositor". For more on this invention, see Bruce Michelson, Printer's Devil: Mark Twain and the American Publishing Revolution (Berkeley: University of California Press, 2006).

13. Stanley Morison, Memorandum on a Proposal to Revise the Typography of 'The Times' (London : The Times, 1930) and Supplement to the Memorandum (London: The Times, 1931). See also the special issue "The Times and its New Roman Type" of The Monotype Recorder (vol. 21, September-October 1932) and Claire Hoertz Badaracco, Trading Words: Poetry, Typography, and Illustrated Books in the Modern Literary Economy (Baltimore: Johns Hopkins University Press, 1995), 106-111.

14. Martyn Lyons, A History of Reading and Writing in the Western World (New York: Palgrave Macmillan, 2010), 139.

15. William J. Sonn, Paradigms Lost : The Life and Deaths of the Printed Word (Lanham, MD: Scarecrow Press, 2006), 166.

16. Lyons, A History of Reading and Writing, 140. See also Svend Dahl, History of the Book (New York: Scarecrow Press, 1958), 220 and Reinhard Wittmann, Geschichte des deutschen Buchhandels. Ein Überblick (München: C.H. Beck, 1991), 271. 
17. Badaracco, Trading Words, 4. Morison describes the printing trade in the U.K. in 1930 as "ranking as the fourth industry in the country" (Morison, Memorandum, 296).

18. Steven Roger Fischer, A History of Reading (London: Reaktion Books, 2003), 281.

19. John P. Feather, "The Book in History and the History of the Book", The History of Books and Libraries: Two Views, ed. John P. Feather and David McKitterick (Washington, DC: Library of Congress, 1986), 6.

20. Lyons, A History of Reading and Writing, 138.

21. Cathy N. Davidson, "Towards a History of Books and Readers", American Quarterly 40.1 (1988) : 12.

22. Rolf Engelsing, Analphabetum und Lektüre. Zur Sozialgeschichte des Lesens in Deutschland zwischen feudaler und industrieller Gesellschaft (Stuttgart: Metzler, 1973) and Der Bürger als Leser. Lesergeschichte in Deutschland 1500-1800 (Stuttgart: Metzler, 1974). See also Erich Schön, Der Verlust der Sinnlichkeit oder die Verwandlung des Lesers. Mentalitätswandel um 1800 (Stuttgart : Cotta, 1987).

23. Simon Eliot and Andrew Nash, "Mass Markets: Literature", The Cambridge History of the Book in Britain, ed. John Barnard, D. F. McKenzie, David McKitterick, and I. R. Willison, 7 vols. (Cambridge : Cambridge University Press, 1998), 6: 440. Of course the opposite also happened, as "publishers had always exploited form and price to appeal to different markets. Moxon's Popular Poets, first issued in 1870 at $3 \mathrm{~s}$ 6d, was then presented in more expensive formats as Moxon's Royal Poets (7s 6d) and Moxon's Library Poets (5s). [...] It was common for series to offer a range of binding styles-vellum, gilded leather, cloth, buckram, paper-at different prices. [...] Warne's Albion Poets was available in four different bindings and prices : $3 \mathrm{~s} 6 \mathrm{~d}$ through $5 \mathrm{~s}$ and $7 \mathrm{~s} 6 \mathrm{~d}$ to $10 \mathrm{~s}$ 6d. Mass sales and cheapness was not the only option pursued." (Ibid., 441)

24. Stephen Colclough, "Distribution", The Cambridge History of the Book in Britain, ed. John Barnard, D. F. McKenzie, David McKitterick, and I. R. Willison, 7 vols. (Cambridge : Cambridge University Press, 1998), 6: 239. For more on print runs of best-selling books in nineteenthcentury France, see Martyn Lyons, "Les best-sellers", Histoire de l'édition française, ed. Henri-Jean Martin, Roger Chartier, and Jean-Pierre Vivet, 4 vols. (Paris: Promodis, 1985), 3: 369-377 and 382-397.

25. Simon Eliot and Andrew Nash, "Mass Markets: Literature", 423.

26. This was related to the so-called "Klassikerjahr" in 1867, going back to the Prussian Law dating from 1837 for the right of reprinting any text of an author during his lifetime and 30 years after his death. From 1867 on the entire collection of German classical texts was in the public domain, which led to the formation of new publishing houses like Reclam. See the contributions in Reclam. 125 Jahre Universal-Bibliothek. 1867-1992, ed. Dietrich Bode (Stuttgart: Reclam, 1992).

27. Fischer, A History of Reading, 282.

28. Ibid., 280.

29. Lyons, A History of Reading and Writing, 142.

30. Jean-Yves Mollier and Marie-Françoise Cachin, "A Continent of Texts: Europe 1800-1890", A Companion to the History of the Book, ed. Simon Eliot and Jonathan Rose (Oxford: Blackwell, 2007), 308.

31. Eliot and Nash, "Mass Markets", $6: 424$.

32. See Graham Law and Robert L. Patten, "The Serial Revolution", The Cambridge History of the Book in Britain, ed. John Barnard, D. F. McKenzie, David McKitterick, and I. R. Willison, 7 vols. (Cambridge : Cambridge University Press, 1998), 6: 144-171 and the French standard works Lise Queffélec, Le roman-feuilleton français au XIX ${ }^{e}$ siècle (Paris: Presses Universitaires de France, 1989) and Lise Dumasy, La querelle du roman-feuilleton. Littérature, presse et politique, un débat précurseur (Grenoble: Éditions littéraires et linguistiques de l'université de Grenoble, 1999).

33. Joseph McAleer, Popular Reading and Publishing in Britain, 1914-1950 (Oxford: Clarendon Press, 1992), 51.

34. Wittmann, Geschichte des deutschen Buchhandels, 314. 
35. James L. W. West III, "The Expansion of the National Book Trade System", A History of the Book in America, ed. Carl F. Kaestle and Janice Radway, 5 vols. (Chapel Hill: University of North Carolina Press, 2009), $4: 85$.

36. Michael Winship, "Manufacturing and Book Production", A History of the Book in America, Volume 3: The Industrial Book 1840-1880, ed. Scott E. Casper, Jeffrey D. Groves, Stephen W. Nissenbaum, and Michael Winship (Chapel Hill : University of North Carolina Press, 2007), 59-60.

37. Janice A. Radway, A Feeling for Books: The Book-of-the-Month Club, Literary Taste, and Middle-Class Desire (Chapel Hill: University of North Carolina Press, 1997), 132-133.

38. Mary Noel, Villains Galore: The Heyday of the Popular Story Weekly (New York: Macmillan, 1954), 5-6.

39. Simon Eliot, "Circulating Libraries in the Victorian Age and After", The Cambridge History of Libraries in Britain and Ireland, ed. Peter Hoare, 3 vols. (Cambridge : Cambridge University Press, 2006), 3: 125.

40. Ibid., 128.

41. Martyn Lyons, "New Readers in the Nineteenth Century: Women, Children, Workers", A History of Reading in the West, ed. Guglielmo Cavallo and Roger Chartier, trans. Lydia G. Cochrane (Amherst: University of Massachusetts Press, 1999), 334.

42. Ibid., 333.

43. Lyons, A History of Reading and Writing, 148. For a more detailed description, see Wittmann. Geschichte des deutschen Buchhandels, 253-255. More than 90\% of the contemporary reading public in Austria and Germany read books through circulating libraries.

44. Cathy N. Davidson, Revolution and the Word: The Rise of the Novel in America (Oxford: Oxford University Press, 1986), 41.

45. Noah Porter, Books and Reading (New York: Scribner's, 1881), 6.

46. Qtd. in John William Tebbel, A History of Book Publishing in the United States, 4 vols. (New York:

R. R. Bowker, 1975), 2: 502-503.

47. James Russell Lowell, The Function of the Poet and Other Essays (Boston: Houghton Mifflin, 1920), 62-63. Complaints concerning the quantity of books and the problems associated with reading them all actually date back to antiquity. See, for example, Tsien, The Bad Taste of Others, 14-38 and Bernhard Metz, "Bibliomania and the Folly of Reading", Comparative Critical Studies 5.2 (2008): 249-269.

48. Radway, A Feeling for Books, 139.

49. Qtd. in Q. D. Leavis, Fiction and the Reading Public (London : Chatto and Windus, 1939), 9.

50. Ibid.

51. Andrew Nash, "Literary Culture and Literary Publishing in Inter-war Britain", Literary Cultures and the Material Book, ed. Simon Eliot, Andrew Nash, and Ian Willison (London: British Library, 2007), 324-325.

52. Leavis, Fiction and the Reading Public, 162.

53. Ibid., 19.

54. Ibid.

55. Ibid., 17.

56. Ibid., 35.

57. Ibid.

58. Pierre Bourdieu, The Rules of Art: Genesis and Structure of the Literary Field, trans. Susan Emanuel (Stanford: Stanford University Press, 1995), 142.

59. Ellen Gruber Garvey, "Ambivalent Advertising: Books, Prestige, and the Circulation of Publicity", A History of the Book in America, ed. Carl F. Kaestle and Janice Radway, 5 vols. (Chapel Hill : University of North Carolina Press, 2009), 4: 171.

60. Bourdieu, The Rules of Art, 170. 
61. Matt Erlin, "How to Think About Luxury Editions in Late Eighteenth- and Early NineteenthCentury Germany", Publishing Culture and the "Reading Nation": German Book History in the Long Nineteenth Century, ed. Lynne Tatlock (Rochester: Camden House, 2010), 33-35. Luxury bindings are at least as old as the book as codex and not related to industrial production. Otto Mazal names the fourth century as a starting point and refers to the criticism of church fathers like Jerome or John Chrysostom (Mazal, Einbandkunde, 3). For more on luxury, taste, and typesetting, see Michael Cahn, "Opera Omnia : The Production of Cultural Authority", History of Science, History of Text, ed. Karine Chemla (Dordrecht: Springer, 2004), 81-94.

62. Ronald J. Zboray, "Antebellum Reading the Ironies of Technological Innovation", American Quarterly 40.1 (1988): 67.

63. Zboray, "Antebellum Reading", 74. For more on the "book fool" or "bibliomaniac" as a detested figure, see Metz, "Bibliomania", 250-263.

64. McKitterick, "Changes in the Look of the Book", 99.

65. Radway, A Feeling for Books, 137.

66. Ibid., 145.

67. Mary Benton, "Too Many Books': Book Ownership and Cultural Identity in the 1920s", American Quarterly 49.2 (1997) : 279.

68. Ibid., 280. For an analysis of advertising in German magazines, see Ursula Rautenberg, "Das Buch in der Alltagskultur. Eine Annäherung an zeichenhaften Buchgebrauch und die Medialität des Buches", Buchkulturen. Beiträge zur Geschichte der Literaturvermittlung. Festschrift für Reinhard Wittmann, ed. Monika Estermann, Ernst Fischer, and Ute Schneider (Wiesbaden: Harrassowitz, 2005), 487-516.

69. Jeffrey D. Groves, "Judging Literary Books by Their Covers: House Styles, Ticknor and Fields, and Literary Promotion", Reading Books : Essays on the Material Text and Literature in America, ed. Michele Moylan and Lane Stiles (Amherst: University of Massachusetts Press, 1996), 76.

70. Ibid., 93.

71. Ibid., 78.

72. For more on the relationship between taste and prestige with regard to dust jackets, see Mazal, Einbandkunde, 326.

73. Pierre Bourdieu, Distinction: A Social Critique of the Judgement of Taste, trans. Richard Nice (Cambridge: Harvard University Press, 1984), 499-500.

74. Franco Moretti, Graphs, Maps, Trees : Abstract Models for a Literary History (London: Verso, 2005) and Distant Reading (London: Verso, 2013).

75. See, for example, Moretti, Distant Reading, 173-176 and "Critical Apparatus: The Market for Novels-Some Statistical Profiles", The Novel, ed. Franco Moretti, 2 vols. (Princeton : Princeton University Press, 2006), 1: 427-530.

76. For the period between 1830 and 1914 in the U.K., see Colclough, "Distribution", 238-280. For George Macy's Limited Editions Club (1929-1939), see Badaracco, Trading Words, 150-190.

\section{AUTHORS}

\section{ANTHONY ENNS}

Associate Professor of English, Dalhousie University in Halifax, Nova Scotia 
BERNHARD METZ

Postdoctoral Fellow, Friedrich Schlegel Graduate School of Literary Studies, Berlin 